\title{
Land Revenue Assessment: A Case Study
}

\author{
by \\ B.A. AZHAR*
}

This study has two objects: the primary object is to analyse the traditional procedure of land revenue assessment, and to examine its relevance under present conditions. An ancillary object is to calculate the existing burden of land revenue and to explore the scope for additional taxation.

Land revenue settlement work is undertaken on a district basis but assessments are made tehsil-wise. Each tehsil is divided into a number of assessment circles which comprise groups of villages with similar fiscal and agricultural features. Thus the unit of land revenue assessment is the assessment circle and not the village. Nili Bar circle in Tehsil Lodhran of Multan District has been selected for study for two reasons. Firstly, its fertile land, perennial irrigation and fairly intensive cultivation make it representative of the irrigated areas in the province. Secondly, its revenue settlement was done recently (1966), nearly half a century after the last settlement in 1921. This provides a unique opportunity to study changes in economic conditions, the relevance of old methods of assessment and the incidence of land revenue before and after assessment.

The total number of villages in the circle is 126 . The soil is generally fertile though the sub-soil water is saline. The average annual rainfall is only 5 inches and the main source of irrigation is the perennial canal known as the Pakpattan Canal or the Nili Bar Canal. In recent years a large number of tubewells have been sunk, and the number mentioned in the 1966 settlement report is 172 [1]. The total area of the circle is $1,50,865$ acres. In 1921, the cultivated area was only 39,969 acres or nearly 27 per cent of the total area. In 1966, the cultivated area rose to $1,11,029$ acres or about 73 per cent of the total area. This increase, which amounts to about 177 per cent, was made possible by the extension of canal irrigation. At present nearly 90 per cent of the cultivated area is irrigated by canal water.

The population of the circle was 38,647 in 1921 . It increased to 71,854 in 1961. The average size of holdings decreased from 18 acres in 1921 to only 7 acres in 1966. The average price of land in 1966 was Rs. 1,033 per acre which was 6 to 7 times higher than that in 1921. There was practically no indebtedness at the time of 1966 Settlement, nor was there any area committed to usufructuary or other mortgage.

-Dr. Azhar is an Honorary Advisor of the PIDE and is Joint Econ om ic Advisor, Ministry of Finance, Government of Pakistan, Islamabad. The views expressed in the paper are solely in his personal capacity and have nothing to do with his official position. 
There were significant changes in the cropping pattern between 1921 and 1966. The major changes are shown in the following table:-

\begin{tabular}{|c|c|c|}
\hline Crop & 1921 & 1966 \\
\hline $\begin{array}{l}\text { Cotton (American) } \\
\text { Cotton (desi) } \\
\text { Fodder } \\
\text { Sugarcane } \\
\text { Other crops }\end{array}$ & $\begin{array}{l}6 \% \\
18 \% \\
15 \%\end{array}$ & $\begin{array}{r}30 \% \\
8 \% \\
2 \% \\
6 \%\end{array}$ \\
\hline Total Kharif & $39 \%$ & $46 \%$ \\
\hline $\begin{array}{l}\text { Wheat } \\
\text { Gram } \\
\text { Fodder } \\
\text { Other crops }\end{array}$ & $\begin{array}{l}42 \% \\
1 \% \\
10 \% \\
8 \%\end{array}$ & $\begin{array}{l}35 \% \\
4 \% \\
9 \% \\
6 \%\end{array}$ \\
\hline Total Rabi & $61 \%$ & $54 \%$ \\
\hline
\end{tabular}

It will be seen that while no sugarcane and American cotton were sown in 1921, 30 per cent of the cropped area was under American cotton and 2 per cent under sugarcane in 1966. Both of these are cash crops. The area under Kharif crops increased considerably which shows that, with the advent of canal water, larger areas were put under cash crops. The Kharif-Rabi ratio which was 39:61 in 1921 changed to 46:54 in 1966 showing a gradual shift from subsistence farming to commercial farming. Kharif fodders declined from 18 per cent in 1921 to only 8 per cent in 1966 . Another noteworthy fact is that the average figures for crop failure (kharaba) declined from 12 per cent in 1921 to only 1 per cent in 1966.

\section{LAND REVENUE ASSESSMENT}

Land revenue is assessed at 25 per cent of the net assets of an estate or a group of estates. The net assets are the estimated surplus produce of an estate remaining after the deduction of ordinary expenses of cultivation from gross produce. These include payments borne by the land-owner customarily in respect of (i) water rates, (ii) maintenance of means of irrigation, (iii) maintenance of embankments (iv) supply of seed, (v) supply manure, (vi) improved farm implements, (vii) concessions with regard to fodder, (viii) special abatement made for fallow land or bad harvests, (ix) cost of collection of rent, (x) allowance for shortage in the collection of rent, (xi) interest charges payable in respect of advances made to tenants for the purposes of cultivation, (xii) wages or customary dues paid to artisans or menials whose products or labour are utilised for the purposes of cultivation or harvesting, and (xiii) the share retainable by a tenant if the land were let to him at the prevalent rate [2].

In calculating the money value of the gross produce, the Settlement Officer has to estimate (i) the matured area under each crop, (ii) the average yield per acre, and (iii) the average price for each crop. 
The matured area under each crop can be ascertained more or less accurately from the revenue records. A more difficult problem is to estimate yields. The Settlement Manual [3, paragraph 324] lays down that "in essaying to make the best estimate in his power a Settlement Officer must be guided by the results of experimental cuttings, by his own observations and information gathered from trustworthy persons, by the accounts of land owners or mortgages, where obtainable, and by the yields assumed for similar tracts elsewhere. "The Manual also lays down detailed instructions (Appendix ' $X$ ') for conducting crop cutting experiments for the determination of crop yields. However, as the experiments are generally conducted by statistically inexperienced staff and the area covered is rather small, the results are not very reliable. The estimates of yields are usually based on the Settlement Officer's subjective judgement. More often than not, the yields considered for assessment are much lower than the actual yields. This is borne out by the latest assessment of the Nili Bar circle
as can be seen from Appendix B.

The most difficult problem is to formulate an estimate of the prices of various crops (commutation prices), so as to assess the money value of the produce. The guiding principle, laid down in the Land Revenue Assessment Rules [3] is that these prices should be the average prices likely to be obtained by agriculturists from village traders for their crops. Under the Punjab Land Revenue Act of 1871, the commutation prices were the average prices of the preceding twenty years, but this was subsequently changed. The current Settlement Manual [3] states that "the only safe plan is to take the average of a not be dissimilar"

It can be seen that the determination of prices for use in produce estimates is tantamount to forecasting the trend of prices during the next 25 years or so for which the new settlement is expected to run. The procedures adopted by the Settlement Officers to forecast prices are archaic and often misleading, as will be seen later in the case study.

The land revenue demand of the Nili Bar Assessment Circle since the previous settlement 1921 is shown below:-

\begin{tabular}{lr}
$\frac{\text { Year }}{1920-21}$ (Settlement) & Demand $R$ s. \\
& 98,876 \\
\hline $1956-57$ & 284,803 \\
$1957-58$ & 280,515 \\
$1958-59$ & 270,969 \\
\hline Average of 4 years & 292,018 \\
\hline $1963-64$ & 282,076 \\
$1964-65$ & 363,851 \\
$1965-66$ (Settlement) & 366,041 \\
\hline
\end{tabular}


It will be observed that the demand in 1964-65 was over 3 times larger than in the 1921 settlement. This increase can be explained by the great expansion in the cultivated area (177 per cent) and the 25 per cent enhancement in land revenue rates in 1962. It is interesting, however, to observe that the demand created in 1966 on the basis of the fresh settlement was lower than the actual collections of 1963-64 and 1964-65. The assessment was based on the average demand for 5 selected years (1956-57 to 1959-60) which was enhanced only by 24 per cent. It was laid down in the Land Revenue Act of 1928[4] that the previous assessment cannot be raised by more than two-third (now onehalf in the new Act) in any individual estate, or by more than a quarter in the assessment circle as a whole. This constraint, however, did not operate fully in the present case as the demand was fixed at the low level of Rs. 7.5 lakh. The Settlement Officer observed in his Report [1]. "The current demand includes 25 per cent increase over and above the last assessment rates as authorised under the Ordinance in 1962 .... After the introduction of regular canal system in the Tehsil after the last settlement, land revenue assessment was not made according to quarter net assets estimates but 'Jama' was increased randomly. Hence, under these circumstances, the Assessing Officer is not strictly bound to follow the 25 per cent increase formula".

\section{DETERMINATION OF NET ASSETS IN NILI BAR}

\section{(a) Rate of Batai}

At the time of the 1966 settlement the batai rates were 50 per cent in the Nili Bar Circle, with half of the land revenue payable by the land-lord and the other half by the tenant. Similarly, abiana was paid half and half by the landlord and the tenant. The Settlement Officer allowed an amount of Rs. 2 per matured acre as deduction from the common heap, for the use of chemical fertilizers. According to the general conditions of the contrict between the landlord and the tenant, the entire cost of seed was borne by the tenant except for sugarcane where the landlord shared 50 per cent of the cost.

\section{(b) Prices}

The prices approved by the Board of Revenue for the 1966 Settlement were based on the average of the period 1948-61, and are shown in Appendix 'A'. For comparison, the prices adopted in the 1921 Settlement are also shown in the Appendix. The prices used for the purpose of this study are shown there too. It can be seen that the prices adopted for assessment were far too low even in 1966 and are expected or assumed to remain at that low level throughout the settlement period i.e., till 1991. This could not be more unrealistic. The Settlement Officer observed in his report that the actual prices at the time of settlement were at least 50 per cent higher than those used for the purpose of assessment. The low figures resulted primarily from the statistical averaging of historically distant prices (1948-61). It would have been more realistic to calculate the trends on the basis of past data and make projections for the future. It should, however, be added that price forecasting over periods as long as 25 years is a hazardous exercise despite the general belief that the trend of rising prices is not likely to be reserved. This is 'so because the individual prices may behave quite differently in different cases, although the general level of prices may be going up. A sliding scale system would be safer [5] whereby the agriculturists get remissions whenever prices fall and the Government shares in prosperity wherever prices rise. However, the sliding scale system 

was abolished when the West Pakistan Land Revenue Act came into force in
1967.1

The yields assumed in the 1966 Settlement and those in the 1921 Settlement are shown in appendix ' $\mathrm{B}$ '. The yields assumed for the present study are also shown in the appendix. The yields in 1966 should have been substantially higher than those in 1921 on account of improved seeds and better cultivation, use of chemical fertilizers, intensive cultivation, better irrigation facilities and better farming practices. The improvements, however, are not reflected in the yields assumed for the settlement. In some cases the yields assumed in 1966 are lower than those in 1921. The assumed yields, especially of crops like wheat and rice, are rather unrealistic in view of the recent 'Green Revolution'. As reported by the Settlement Officer, the assumed yields were fixed not with reference to average lands but to some of the poorest lands in the circle. Thus. the yields for the calculation of produce estimates were kept delibrately low. It would have been better to take the latest average yields and calculate, on this. basis, those to be adopted for the settlement, thus incorporating the trends in productivity likely to prevail during the period of the settlement.

\section{(c) Mueens' Dues}

Agricultural workers known as 'Mueens' such as Lohar, (black-smith), Terkhan (carpent $: \mathrm{r}$ ), Kumhar (potter), Odava (winnower), Lava (reaper) and Choni (cotton picker) are paid from the common heap. In the Nili Bar, Circle, Lohar and Tarkhan are paid 10 seers of cotton and one maund of wheat each per square of land. Lava gets 1/20th of the harvest and Odawa one seer per maund and the Choni $1 / 20$ th of the quantity picked. The total expenditure works out to be approximately 8 per cent of gross value. No change has been assumed in this proportion.

In order to calculate net assets a number of deductions are made from the gross value of produce. In the 1966 settlement, 'Mueen' dues were allowed out of the common pool at 8 per cent of the gross value, the cost of fertilizers at Rs. 2 per acre, and the cost of sugarcane seed at Rs. 90 per acre. Together they constitute 11 per cent of the gross value. Out of the remaining 89 per cent, 50 per cent was allowed as the landlord's share. Deducted from this was half the amount of Abiana paid by the landlord, and to the balance half the land revenue paid by the tenant was added. This gave the figure of net assets or the landlord's net income. According to these calculations the landlord's net income per acre was only Rs. 57 in 1966, which appears to be too low a figure for the canal irrigated areas.

${ }^{1}$ There were two systems of sliding scale in West Pakistan prior to the introduction of the West Pakistan Land Revenue Act, 1967. In the Punjab the sliding scale system was introduced
in the settlement of Lyallpur District in 1936 when prices had fallen and it was difficult to forecast the trend of future prices. The object of the new system was to enable the Government to fix its demand high enough to take into account the likelihood of prices rising to the average level of the last 20 or 30 years, simultaneously making it possible to adjust this demand on each harvest to current prices. Thus it allowed only downward adjustment of demand. On the other hand in Sind the land revenue demand could move up without any restriction with the increase in the prices of paddy, wheat and cotton. In 1961, however, ceiling prices were fxed in respect of these crops so that the application of the
sliding scale system became virtually inoperative. 


\section{QUARTER-NET-ASSETS OR THEORETICAL LAND REVENUE}

The quarter-net-assets, as worked out by the Settlement Officer in the 1966 Settlement for the Nili Bar Circle, represent the theoretical share of the Government and are given below:-
(i) Total net assets
.. Rs. 54.5 lakhs
(ii) Quarter net assets
.. Rs. 13.6 lakhs
(iii) Land revenue (theoretical) per matured acre
.. Rs. 14.16
(iv) Rate per matured acre (1966 Settlement)
. Rs. 3.64

It is interesting to observe that from the much under-estimated net assets (resulting from unduly low prices and yields adopted for the settlement), the demand proposed by the settlement officer was only Rs. 3.50 lakb or Rs. 3.64 per matured acre. This equals the rate in 1921, and will continue till 1991 when the next settlement becomes due. As the demand was fixed at a level lower than the actual demand for 1964-65, the settlement was rendered completely infructuous and damaging from the fiscal point of view.

\section{Cesses and Malkana}

In addition to land revenue, the following cesses are also levied at present in the form of a percentage of land revenue:-

\section{Percentage of Land Revenue}
(i) Local rate
50
(ii) Development cess
35
(iii) Panchotra
(iv) Masjid Fund
2

The imposition of cesses would appear to represent an administrative attempt to by-pass legal constraints, whereby land revenue cannot be raised during the currency of a settlement or the demand cannot be increased at resettlement beyond certain prescribed proportions. Inspite of these cesses and rates, however, the total incidence of land tax remains quite low.

\section{AN ALTERNATE ESTMMATE OF NET ASSETS}

It has been seen above that even at the low prices and yields adopted by the Settlement Officer, the land revenue demand could have been four times the one fixed had there been no legal or other constraints on increasing the rate of assessment. A calculation of net assets at different prices and yields must remain a purely academic exercise so long as these constraints continue. Nevertheless it would serve a useful purpose to indicate the potential increase in revenue once the constraints are removed. Net assets have been reassessed on the basis of average yields and prices during (i) 1967-68 to 1971-72, and (ii) $1969-70$ to $1971-72$. 
The revision of net assets is based on the following assumptions:-

(i) Abiama

The average water charges for Multan district of Rs. 13 per acre have been used rather than Rs. 3.50 per acre assumed by the Settlement Officer.

(ii) Fertiliner

The fertilizer cost used for calculating net assets averaged Rs. 15 per irrigated acre rather than Rs. 2 per acre assumed by the Settlement Officer.

(iii) Seeds

The weighted average seed cost per acre for Multan district works out to Rs. 12 and has been adopted for determining net assets. The Settlement Officer allowed deduction only for sugarcane seed at Rs. 90 per acre.

Under the land reforms introduced in March 1972, the payment of land revenue, water rates and the cost of seed became the sole responsibility of the landlord, while the remaining inputs are shared equally between him and the tenant. This has considerably reduced the legal share of the landlord in gross produce. It would mean that out of the gross value, only the dues of the mueens at 8 per cent will be deducted in full. The balance will be divided equally between the landlord and the tenant. Half the cost of chemical fertilizers and the full cost of seeds as well as Abiana will be deducted from the landlord's share to arrive at net assets.

An estimate of net assets on the basis of prices and yields assumed for the purpose of this study and in the light of the recent land reform measures works out as follows:-

Recalculated Gross Value

(Appendices C, CC, D and DD)

(i) Rs. 3,29,43,244

Gross value in 1966 Settlement

(ii) Rs. $\quad 3,44,67,458$

Gross value in 1966 Settlement

Recalculated net Assets

Rs. $1,23,79,789$

(i) Rs. $\quad 1,19,39,000$

(ii) Rs. $1,26,40,139$

Net Assets in 1966 Settlement

Rs. $54,49,165$

Recalculated Quarter Net Assets

(Theoretical Land Revenue)

(i) Rs. $\quad 29,84,750$

(ii) Rs. 31,60,033

Quarter Net Assets in 1966

Recalculated Theoretical

Incidence per matured Acre

Rs. $13,62,291$

(i) Rs.

31.09

(ii) Rs. $\quad 32.95$

Theoretical Incidence in 1966 Settlement

Rs.

14.16

Rates of net Assets to Gross Value

(a) Recalculated

(b) 1966 Settlement

(i) Rs.

(ii) Rs.

Rs. 
It will be seen that the net assets worked out in the 1966 Settlement were grossly underestimated. The recalculated net assets are nearly 125 per cent higher than the ones estimated by the Settlement Officer. The land revenue demand could theoretically be as high as Rs. 30 to 32 lakhs compared to the mere-Rs. 3.5 lakhs fixed by the Settlement Officer. The revenue demand fixed in 1966 which was as low as 6.5 per cent of the net assets would be reduced further to only 2.8 per cent of the recalculated net assets compared to the theoretically changeable 25 per cent. By the time the next settlement becomes due in 1991, the incidence of land revenue as a percentage of net assets would be almost nullified unless the constraints are removed or modified.

\section{CONCLUSIONS}

No useful purpose can be served by fresh land revenue assessments unless legal and other constraints on the raising of demand over the previous assessment are removed. In a period of rapidly changing technology and rapid price increases such constraints defeat the purpose of the settlement.

Forecasting the course of prices for a settlement period of 25 years or so is an exercise in speculation. Consequently the duration of settlement should not exceed 10 years. In a period of rising prices, statistical averaging of price data of historically distant years can give misleading results. Commutation prices adopted on the basis of such averaging would tend to be too low. If the duration of settlement is 10 years, the trend of past 10 years could be statistically projected over the next 5 years and the resulting prices could be adopted for settlement.

Alternatively, average prices of the last 3 to 5 years could be adopted for the purposes of assessment and the sliding scale system used to give remissions in years of low prices or to benefit the exchequer in years of high prices.

It is also necessary that yields for estimating net assets be in reference to the average and not to the poorest lands in the circle. Trends in productivity, expected during the coming settlement should also be reflected in yield estimates adopted for assessment. Land revenue assessment become hopelessly out of date in a few years with the fast rate of change in the farm sector. If full scale settlements cannot be repeated every ten years or so, an alternative would be to revise demand on the basis of price and productivity indices every 5 years. Moreover possibility of speeding up land revenue settlements by the use of computer technology should be explored. 
Appendix 'A'

PRICES.

Name of the crop

\begin{tabular}{|c|c|} 
Unit of \\
measure- \\
ment
\end{tabular} \mid $\begin{gathered}1921 \\
\text { Settle- } \\
\text { ment }\end{gathered}$

\section{(1)}

(2)

(3)
1966

Settlement
Present studya

$1967-68$ to $1969-70$

1971-72 (average)
(4) (5)

\section{Maund Rs.Ps. Rs.Ps.}

Rice

Wheat

Cotton (American)

2.00

8.50

18.00

18.50

2.56

8.50

15.00

15.00

Cotton (desi)

Gram

Barley

Kharif Pulses

Til

Sugarcane

Vegetable (Kharif)

Fodder (Kharif)

Rabi Pulses

Other Oil Seeds (Rabi)

Tobacco

Rabi Vegetables

Rabi Fodder

\begin{tabular}{|c|c|c|c|c|}
\hline " & 2.00 & 8.50 & 18.00 & 18.50 \\
\hline " & 2.56 & 8.50 & 15.00 & 15.00 \\
\hline ", & - & 23.50 & 35.00 & 40.00 \\
\hline$"$ & 6.12 & 18.50 & 30.00 & 32.50 \\
\hline " & 2.06 & 7.50 & 20.00 & 20.00 \\
\hline " & 1.62 & 6.50 & 12.00 & 13.00 \\
\hline Acre & 12.90 & 130.00 & 200.00 & 250.00 \\
\hline " & - & 200.00 & 200.00 & 250.00 \\
\hline " & 80.00 & 250.00 & 900.00 & 850.00 \\
\hline " & 60.00 & 200.00 & 600.00 & 600.00 \\
\hline " & 10.00 & 100.00 & 300.00 & 300.00 \\
\hline , & 12.00 & 150.00 & 200.00 & 250.00 \\
\hline ". & 10.37 & 200.00 & 200.00 & 250.00 \\
\hline , & 30.00 & 300.00 & 800.00 & 800.00 \\
\hline$"$ & 60.00 & 200.00 & 600.00 & 600.00 \\
\hline , & 10.00 & 100.00 & 300.00 & 300.00 \\
\hline
\end{tabular}

Prices received by the villagers for their crops were derived from wholesale prices for Multan District which were supplied by Planning Unit of Ministry of Food and Agriculture and Underdeveloped Areas, Agriculture Wing, Islamabad. Out of these prices wero substracted the distributive and marketing costs to get the farm-gate prices. Data on marwas made to forecast prices over the nex given in [6] and references cited in [7]. No attempt rency of the present settlement. 
Appendix 'B'

YIELOS

\begin{tabular}{c|c|c|c|c}
\hline Classification & 1921 & 1966 & \multicolumn{2}{|c}{ Persent study } \\
\hline 1 & & $\begin{array}{l}1967-68 \text { to } \\
1971-72\end{array}$ & $\begin{array}{c}1969-70 \\
\text { to } 1971-72\end{array}$ \\
\hline
\end{tabular}

Cotton American

(Seers per acre)

Irrigated

320

502

490

Cotton Desi

Chahi

Chahi-Nehri

160

240

260

260

Nehri

100

240

260

260

Chahi-Sailab

150

240

260

260

- 240

360

260

Rice

Chahi-Nehri

440

440

610

650

Nehri

400

440

610

650

Wheat

Chahi

360

360

740

Chahi-Nehri

440

360

740

Nehri

280

360

740

Barani

180

200

200

Gram

Chahi

$-\quad 280$

446

305

Chahi-Nehri

280

446

305

Nehri

240

280

305

Barani

120

160

446

160

Barley
Chahi
Chahi-Nehri
Nehri
Barani

360

280

392

440

280

392

280

280

392

160

392

392

392

160

aThe yields of various crops adopted for re-calculating the produce estimate of Nili Bar Circle are the average yields for Multan District supplied by the Planning Unit, Ministry of Food and Agriculture and Underdeveloped Areas, Agriculture Wing, Islamabad. 
Classipication, ChafH(a)

Appendix ' $C$ '

(at 1967-68 to 1971-72 average prices and yieldi)

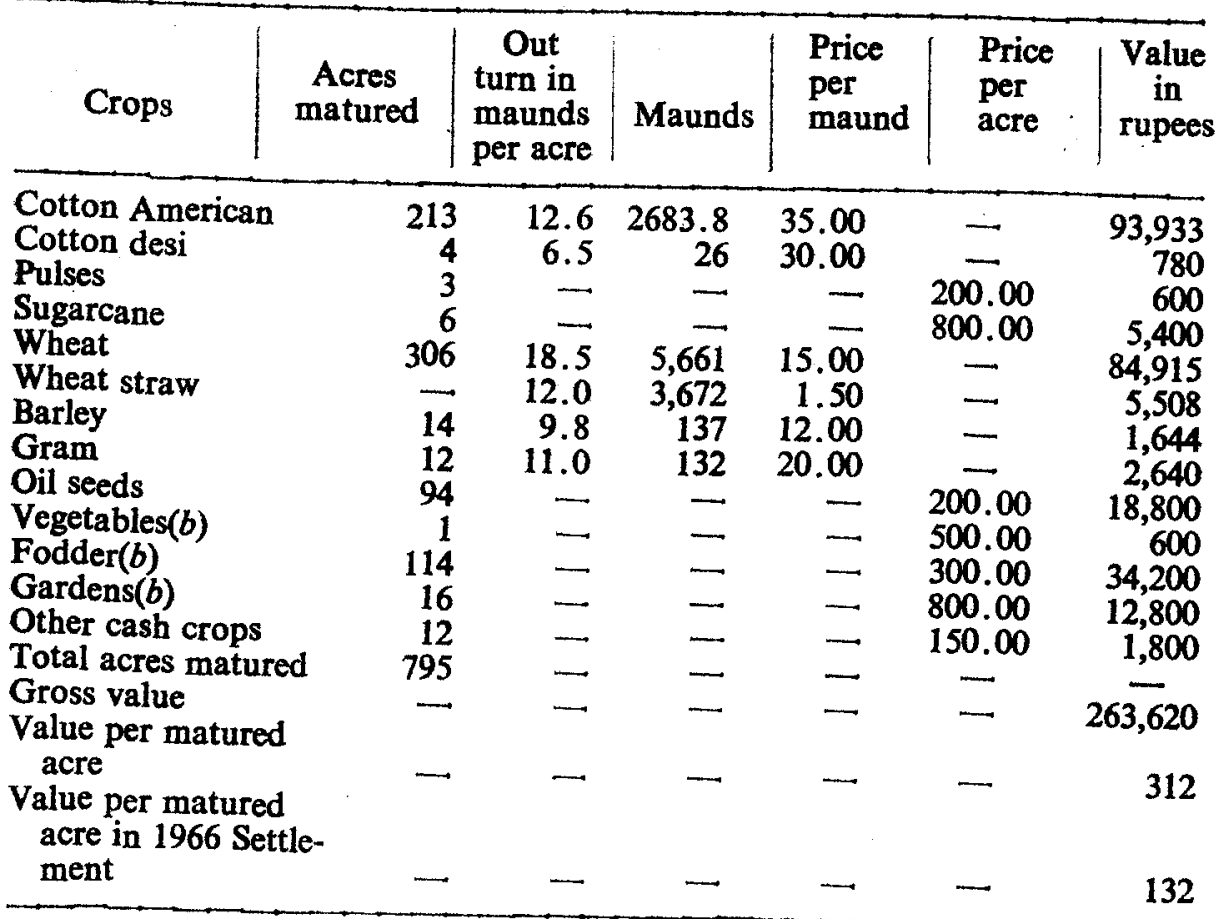

(a) Cropped area under the classification Chahi-Nehri is nominal and can be ignored.

(b) Value per acre are based on a Report by the Harza Engineering Company Inter-

\section{CAlculation OF NET ASSETS}

(i) Gross value

(ii) Less Mueen's dues ( $80 \%$ )

Rs. $\quad 21,090$

(iii) Landlord's share at $30 \%$

Rs. $2,63,620$

(iv) Less half the cost of chemical fertilizers

Rs. $1,21,265$

(v) Less the cost of seeds

(vi) Less Abiana paid by the land lord at Rs. 13 per matured acre

Rs. $\quad 5,963$

Rs. $\quad 9,540$

Rs. 10,335

(vii) Net assets

Rs. $\quad 25,830$

(viii) Quarter net assets

Rs. 95,437

Rs. ' 23,859

(ix) Incidence per matured acre

Rs. $\quad 30.00$

(x) Incidence in 1966 settlement

Rs. 14.89 
Appendix 'CC' TEHSIL LODHRAN ASSESSMENT CIRCLE NILIBAR CLASSIFICATION CHAHI(a) (at 1969-70 to 1971-72 average yields and prices)

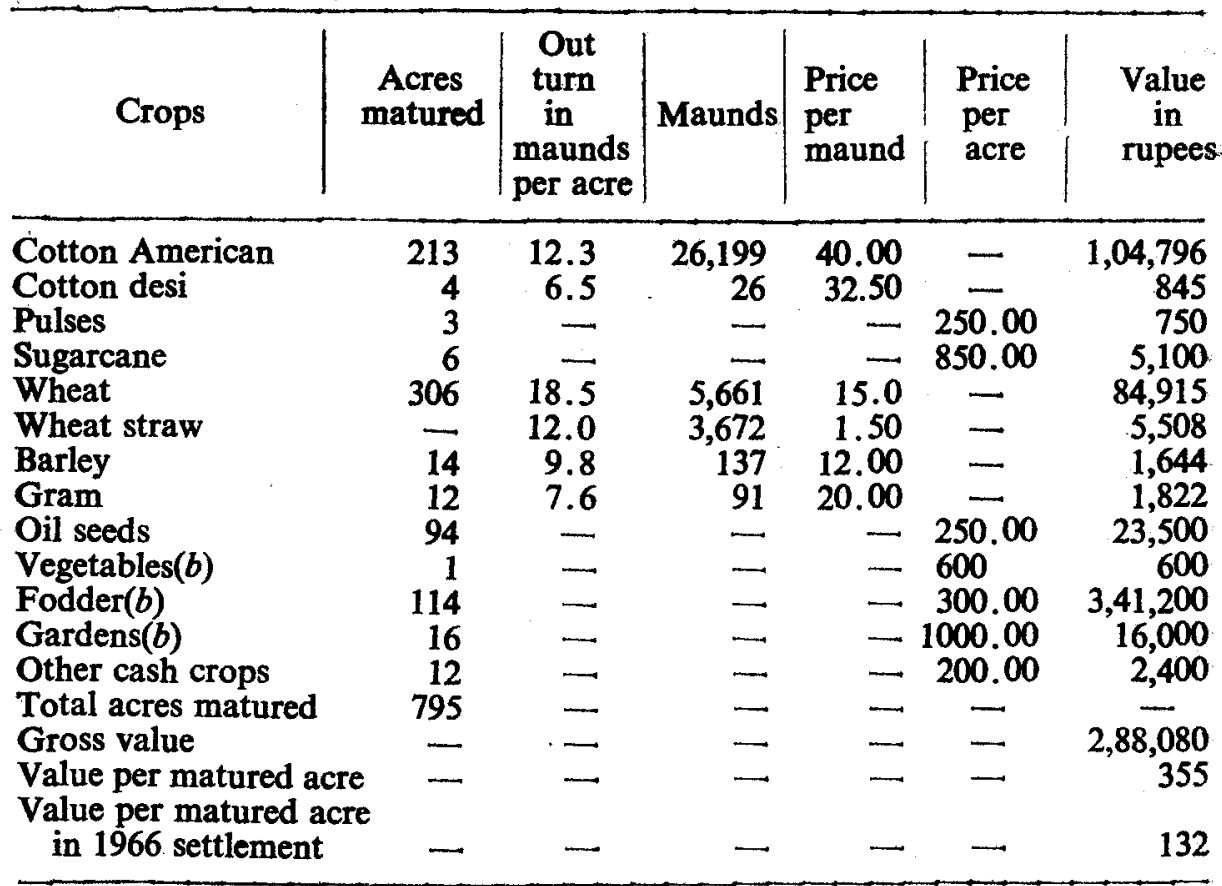

(a) Cropped area under the classification Chahi-Nehri is nominal and can be ignored.

(b) Values per acre are based on a [Report by the Harza Engineering Company International [8].

\section{CALCULATION OF NET ASSETS}

(i) Gross value

(ii) Less mueen's dues (8\%)

(iii) Landlord's share at $50 \%$

(iv) Less half the cost of chemical fertilizers

(v) Less the cost of seeds

(vi) Less Abiana paid by the Landlord at Rs. 13 per matured acre

(vii) Net assets

(viii) Quarter net assets

(ix) Incidence per matured acre

(x) Incidence in 1966 settlement
Rs. $2,82,080$

Rs. 22,566

Rs. $1,29,757$

Rs. $\quad 5,963$

Rs. $\quad 9,540$

Rs. $\quad 10,335$

Total Rs. $\quad 25,830$

Rs. $1,03,920$

Rs. 25,982

Rs. 32.68

Rs. $\quad 14.89$ 
Appendix ' $\mathbf{D}$ '

TEHSIL LODHRAN, ASSESSMENT CIRCLE NILIBAR CLASSIFICATION NEHRI(a) (at $1967 / 68$ to $1971-72$ average yields and prices)

\begin{tabular}{|c|c|c|c|c|c|c|}
\hline Crops & $\begin{array}{c}\text { Acres } \\
\text { matured }\end{array}$ & $\mid \begin{array}{c}\text { Out } \\
\text { turn in } \\
\text { maunds } \\
\text { per acre }\end{array}$ & Maunds & $\begin{array}{l}\text { Price } \\
\text { per } \\
\text { maund }\end{array}$ & $\begin{array}{c}\text { Price } \\
\text { per } \\
\text { acre }\end{array}$ & $\begin{array}{l}\text { Value } \\
\text { in } \\
\text { rupees }\end{array}$ \\
\hline Cotton American & 27,994 & \multirow{2}{*}{$\begin{array}{r}12.6 \\
6.5\end{array}$} & $3,52,724$ & 35.00 & $\longrightarrow$ & $1,23,43,359$ \\
\hline Cotton desi & 376 & & 2,444 & 30.00 & - & 73,320 \\
\hline Pulses & 726 & 一 & 一 & 一 & 200.00 & $1,45,200$ \\
\hline Sugarcane & 2,211 & $18 \overrightarrow{5}$ & - & - & 900.00 & $12,89,900$ \\
\hline Wheat & 33,685 & 18.5 & $6,23,173$ & 15.00 & \multirow{2}{*}{ - } & $93,47,588$ \\
\hline Wheat straw & $=$ & 12.0 & $4,04,016$ & 1.50 & & $6,06,024$ \\
\hline Barley & 301 & 9.8 & 2,957 & 12.00 & - & 35,398 \\
\hline Gram & 3,362 & & 36,982 & 20.00 & $-\overline{0}$ & $7,39,640$ \\
\hline Oil seeds & 5,294 & - & 一 & 一 & 200.00 & $10,58,800$ \\
\hline Tobacco $(b)$ & 42 & - & 一 & - & \multirow{2}{*}{800.00} & 33,600 \\
\hline Vegetables $(b)$ & 156 & 一 & 一 & 一 & & 93,600 \\
\hline Fodder $(b)$ & 19,455 & 一 & - & - & $\begin{array}{l}600.00 \\
300.00\end{array}$ & $8,36,500$ \\
\hline Gardens $(b)$ & 210 & - & - & - & 800.00 & $1,68,000$ \\
\hline Other cash crol & 1,378 & - & 一 & 一 & 150.00 & $2,06,700$ \\
\hline Total acres matured & 95,196 & - & 一 & - & 一 & \multirow{2}{*}{32670624} \\
\hline Gross value & - & 一 & 7 & - & 一 & \\
\hline $\begin{array}{l}\text { Value per matured acre } \\
\text { Value per matured acre }\end{array}$ & & & & & 一 & 343 \\
\hline in 196 & 一 & - & - & - & - & 129 \\
\hline
\end{tabular}

(a) Cropped area under classifications Tubewell-Nehri and Barani is insignificant. (b) Values per acre are based on a Report by the Harza Engineering Company Interna-
tional [8].

(i) Gross value

CALCUlation OF NET ASSETS

(ii) Less Mueen's dues ( $8 \%$ )

(iii) Landlord's share at $50 \%$

(iv) Less half the cost of chemical fertilizers

(v) Less the cost of seeds

(vi) Less Abiana paid by landlord

(vii) Net assets

Total:

(viii) Quarter net assets

(ix) Incidence in 1966 settlement

$(x)$ Incidence per matured acre
Rs. $26,14,370$

Rs. $7,13,970$

Rs. $11,42,352$

Rs. $12,37,548$

Rs. $31,89,066$
Rs. $3,26,79,624$

Rs. $1,50,32,627$

Rs. $1,18,43,563$

Rs. $29,60,890$

Rs. $\quad 14.16$

Rs. $\quad 31.10$ 
Appendix 'DD'

TEHSIL LODHRAN, ASSESSMENT CIRCLE NILIBAR CLASSIFICATION NEHRI(a)

(at 1969-70 to 1971-72 average prices and yields)

\begin{tabular}{|c|c|c|c|c|c|c|}
\hline Crops & $\begin{array}{l}\text { Acres } \\
\text { matured }\end{array}$ & $\mid \begin{array}{l}\text { Out } \\
\text { turn in } \\
\text { maunds } \\
\text { per acre }\end{array}$ & Maunds & $\begin{array}{l}\text { Price } \\
\text { per } \\
\text { maund }\end{array}$ & $\begin{array}{l}\text { Price } \\
\text { per } \\
\text { acre }\end{array}$ & $\begin{array}{l}\text { Value } \\
\text { in } \\
\text { rupees }\end{array}$ \\
\hline Cotton American & 27,994 & 12.3 & $3,44,326$ & 40.00 & 一 & $1,37,73,048$ \\
\hline Cotton & 376 & 6.5 & 2,444 & 32.50 & $\ldots$ & 79,430 \\
\hline Pulses & 726 & 一 & 一 & $\longrightarrow$ & 250.00 & $1,81,500$ \\
\hline Sugarcane & 2,211 & 一 & & 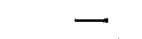 & 850.00 & $18,79,350$ \\
\hline Wheat & 33,685 & 18.5 & $6,23,173$ & 15.0 & 一 & $93,47,588$ \\
\hline Wheat straw & - & 12.0 & $4,04,016$ & 1.50 & - & $6,06,024$ \\
\hline Barley & 301 & 9.8 & 2,950 & 12.00 & - & 35,398 \\
\hline Gram & 3,362 & 7.6 & 25,551 & 20.00 & 一 & $5,10,240$ \\
\hline Oil Seeds & 5,294 & - & - & - & 250.00 & $13,25,500$ \\
\hline Tobacco $(b)$ & 42 & 一 & - & - & 800.00 & 23,600 \\
\hline Vegetable $(b)$ & 156 & 一 & 一 & - & 600.00 & 93,600 \\
\hline Fodder $(b)$ & 19,455 & - & - & - & 300.00 & $58,36,500$ \\
\hline Gardens $(b)$ & 210 & - & 一 & 一 & 1000.00 & $2,10,000$ \\
\hline Other cash crop & 1,378 & - & - & 一 & 200.00 & $2,75,000$ \\
\hline Total acres matured & 95,196 & 一 & - & - & 一 & - \\
\hline Gross value & - & - & - & 一 & - & $3,41,85,378$ \\
\hline Value per matured acr & are & - & 一 & - & 一 & 359 \\
\hline $\begin{array}{l}\text { Value per matured acre } \\
\text { in } 1966 \text { Settlement }\end{array}$ & ere & - & 一 & 一 & - & 129 \\
\hline
\end{tabular}

(a) Cropped area under classifications Tubewells-Nehri and Barani is insignificant.

(b) Values per acre are based on a Report by the Harza Engineering Company international [8].

\section{CALCULATION OF NET ASSETS}

(i) Gross value

(ii) Less Mueen's dues ( $8 \%$ )

(iii) Landlord's share at $50 \%$

(iv) Less half the cost of chemical fertilizers

(v) Less the cost of seeds

(vi) Less Abiana paid by landlord

Total:

(vii) Net assets

(viii) Quarter net assets

(ix) Incidence per matured acre

(x) Incidence in 1966 settlement
Rs. $3,41,85,378$

Rs. $27,34,830$

Rs. $1,57,25,274$

Rs. $7,13,970$

Rs. $11,42,352$

Rs. $12,37,548$

Rs. $31,89,066$

Rs. $1,25,36,210$

Rs. $31,34,053$

Rs. $\quad 32.92$

Rs. $\quad 14.16$ 


\section{REFERENCES}

1. Government of West Pakistan, Assessment Report of the Lodhran Tehsil of the Multan District. (1967).

2. Government of West Pakistan, The West Pakistan Land Revenue Act, 1967.

3. Douie, Sir, James, M., Punjab Settlement Manual 1962 (Fifth edition).

4. Government of the Punjab, The Punjab Land Revenue (Amendment), Act, 1928.

5. Government of the Punjab, The Report of the Land Revenue Committee, 1938.

6. Government of Pakistan, Ministry of Agriculture and Works, Survey Report on Impact of Government Price Policies on Wheat at the Farm Level in Selected Districts of West Pakistan, 1966.

7. Mohammad Afzal, Green Revolution and the Optimal Cropping Patterns inWest Pakistan, Research Report No. 96, Pakistan Institute of Development Economics, 1971.

8. Harza Engineering Company International, An Analysis of the Present Agricultural Economy in Selected Irrigated Areas of the Indus Plains. (A Report prepared for Water and Power Development Authority of West Pakistan, 1964.) 